
CONGO SINCE 1920

African economic history working paper series

No. $46 / 2019$

Dácil Juif

Universidad Carlos III de Madrid

djuif@clio.uc3m.es 
ISBN 978-91-981477-9-7

AEHN working papers are circulated for discussion and comment purposes. The papers have not been peer reviewed, but published at the discretion of the AEHN committee.

The African Economic History Network is funded by Riksbankens Jubileumsfond, Sweden

For submissions, contact:

Erik Green

Department of Economic History

Lund University

P. O. Box 7083 


\title{
Mining, Paternalism and the Spread of Education in the Congo since 1920
}

\begin{abstract}
$\underline{\text { Abstract }}$
This study adds the case of a Belgian colony to a literature that has mainly focussed on differences in school enrolment between French and British African territories. While most studies emphasize the supply- side, especially the constraints on missionary activity, we highlight the role of demand from the colonial mining industry. We use various primary sources to assess quantitatively and qualitatively the development of school enrolment in the Congo since 1920. We show that the regional inequality in education that crystallized in colonial times persisted decades after independence. The provincial disparities are used as a point of departure to explain how the mining industry worked as a catalyst for the expansion of primary school enrolment. The paternalistic policy of "stabilization", i.e. of permanent settlement of workers and their families near the work sites, introduced by the Union Minière du Haut Katanga as well as by most concessionary companies in the Belgian Congo in the mid-1920s, went hand in hand with high investments in primary schooling. The aim of the industry was to save expenses on recruitment and European labour, and to make investments in miners' and their children's education profitable.
\end{abstract}

Note: This paper will be published as a chapter in Diebolt, C., Rijpma, A., Carmichael, S., Dilli, S., \& Stormer, C. (Eds). (2019). Cliometrics of the Family. (Studies in Economic History). Springer.

Acknowledgements: I acknowledge financial support from the Netherlands Organisation for Scientific Research for the project 'Is Poverty Destiny? Exploring Long Term Changes in African Living Standards in Global Perspective' (NWO VIDI Grant no. 016.124.307). For their comments on earlier drafts of this paper I would also like to thank Ewout Frankema and Frans Buelens. 


\section{Introduction}

Education is an important component of living standards. It improves wellbeing in several ways. First, schooling raises individual income and aggregate economic growth (Galor 2011). Furthermore, educated people are healthier because they have a better understanding of hygiene and disease prevention. Several development studies have found a negative correlation between education on the one hand and infant mortality, fertility or early marriage on the other hand (Klasen 2002, Breierova and Duflo 2004). For its positive effects, the expansion of schooling has been promoted by governments of modern welfare states in the past two centuries, and is still an important development goal (Lindert 2004). Education is also the most important predictor of income in the Democratic Republic of the Congo (former Belgian Congo/Zaire) and probably the only factor guaranteeing employment outside agriculture (De Herdt et al. 2010, 2012).

Formal education in Sub-Saharan Africa has, to a large extent, been in the hands of religious orders since the first missionaries settled in the $15^{\text {th }}$ century. The early missionaries' aim was to convert as many people as possible, and the provision of education was the main reward they used to lure Africans into Christianity. Plus, running the school system was the price asked by some colonial states in exchange for granting them tracts of land.

Most of the literature explaining variation in education levels within former colonial Africa has focussed on the difference between French and British attitudes towards missions (White 1996; Grier 1999; Cogneau 2003; Garnier and Schafer 2006; Bolt and Bezemer 2009; Cogneau and Moradi 2014). French education policy was characterized by heavy state intervention and restrictions on missionary activity. Given the French focus on laicity, the colonial state was put in charge of the bulk of school provision. British officials, on the other hand, were interested in saving costs in their colonies and saw in missionaries a cheap provider of education. They granted access to missions of all Christian denominations and gave them a free hand in how to run schools, curricula, etc. It is often claimed that the British laissez-faire attitude yielded higher enrolment levels, and that the distinct education models were inherited and followed by the independent states. For instance, Cogneau and Moradi (2014) exploit the partition of Togoland into British and French territories and show that enrolment rose on the British side of the border while it stagnated on the French side. The cross-border differences in education persisted decades after independence. ${ }^{1}$

The Belgian Congo is less studied and can be regarded as a special case. The state was heavily involved in education and at the same time cooperated with Christian missions. It promoted, via subsidies, the

\footnotetext{
${ }^{1}$ In a similar vein, Gallego and Woodberry (2010) claim that present-day educational attainment in Africa can be traced back to colonial policies encouraging competition between Protestant and Catholic missions or, alternatively, protecting one particular church. The British followed the neutral policy, whereas most Catholic colonial powers favoured Catholic missions.
} 
spread of primary schooling as well as specialized training to meet the labour needs of the economy and polity. Colonial authorities also sought to control the teaching content for fear that education could awake anti-colonial sentiments. However, in practice, education was organized and provided by missionaries. Although subsidies were granted exclusively to Catholic missions, Protestant missionaries were never banned from the Congo territory.

Another stream of the literature has emphasized the pre-colonial conditions shaping the demand and supply of schooling. For instance, referring back to Johnson (1967), Nunn (2012) argues that natural factors constraining missionary settlement in the $19^{\text {th }}$ and early $20^{\text {th }}$ century - such as climate, the disease environment or accessibility by navigable rivers and other trade routes - explain regional disparities in education in colonial times, which persisted until today. Frankema (2012) holds that local (pre-colonial) conditions affecting native demand for Christian missionary education (African agency), such as the prevalence of Islam, were more important than colonial education policy.

While geography and African demand played an important role, this paper argues that a basic factor has not been considered enough in this literature: the demand for labour from colonial industry. The Belgian Congo is an example of a colony where, in contrast to many plantation economies, ${ }^{2}$ the colonial (mining) industry had a positive impact on the spread of indigenous education. It shaped regional inequality in enrolment levels within the territory, which persisted until post-colonial times.

Concessionary companies that engaged in mining and transport, but also in other industries (mainly palm oil and cotton production), developed an increasing demand for skilled labour. After the First World War, rising mechanization and the replacement of Europeans paid in overvalued foreign currency with cheaper African workers, made the need for educated indigenous labour particularly pertinent. The paternalistic policy of stabilization, i.e. of long-term employment and permanent settlement of workers and their families in compounds, was promoted by the colonial government and adopted by most concessionary companies ${ }^{3}$ in the Belgian Congo from the mid-1920s. It made workers' benefits in the form of health services, adequate food and housing, and professional training profitable, as indigenous labour turn-over declined and its productivity rose. The state had a large stake in most concessionary companies and thus played a crucial role in formulating their labour policies. Furthermore, by government regulation, companies of a certain size had to provide (and fund), among other social services, at least minimal educational opportunities for their workers' children - which they did in cooperation with missions (Harris 1946).

\footnotetext{
${ }^{2}$ For instance, in the plantation economies of colonial Latin America, education was not regarded as a necessary requirement for an agricultural labour force that consisted of day labourers, serfs, slaves and subsistence farmers (Galor, Moav and Vollrath 2009; Frankema 2008).

${ }^{3}$ Concessionary (or chartered) companies after 1908 lost the administrative authority that they enjoyed over their territories under Leopold's rule, but the state made sure that the population worked for the company or sold their crops at monopoly prices.
} 
This paper assesses quantitatively and qualitatively the development of formal education in the Belgian Congo. It shows that the regional differences that crystallized in early colonial times persisted decades after independence. The variation in enrolment between provinces is used as a starting point to explain how the industry affected human capital formation. We then focus on the province with the highest enrolment levels, Katanga, and dig deeper into the labour (and education) policies of the Union Minière du Haut Katanga (UMHK), by far the largest and only mining company of the region. After the UMHK introduced the policy of stabilizing its labour force, it not only provided professional training to workers but also primary schooling to their children. Like other large companies in the Belgian Congo - not so much in neighbouring colonies where the "colour bar" prevailed in labour relations - the UMHK promoted the access of the indigenous population to skilled or semi-skilled jobs. To be clear, this paper does not claim that the motives of the companies or the state were purely philanthropic. The objective of the stabilization policy was to save on expensive white labour and on indigenous labour recruitment. The provision of primary education can be seen as a workers' benefit, but it was also meant to impart discipline and work ethic to future generations of workers, the intellectual content being of secondary importance.

We use a variety of primary sources to quantify school enrolment in the colony and after independence, as well as to document public education policy and labour policies and practices of the UMHK. The sources include Annual Reports of the Administration of the Colony of Belgian Congo, the Annual Reports of the UMHK “indigenous labour department" (henceforth: UMHK M.O.I. annual reports) ${ }^{4}$, and the population census of independent Congo (Zaire) of 1984.

The paper is structured as follows. The next section gives a qualitative overview of the history of formal education in the Congo. The third section shows the quantitative development of school enrolment and regional differences in colonial and post-colonial times. Section four aims to explain the role that the industry played in promoting education in the colony. It thereby provides a brief historical overview of the labour policies and practices of the mining industry from its emergence in the 1910s, focussing on the provision of education. Section five concludes.

\section{Formal Education in the Congo: An overview}

The education system in the Belgian Congo was shaped in cooperation between state, industry and church, the famous "colonial trinity" (Boyle 1995, Masandi 2004, Dunkerley 2009). ${ }^{5}$ The missionaries

\footnotetext{
${ }^{4}$ Both state and company started publishing more or less consistent reports since 1920 , and did so until the end of colonial times, in 1960 .

${ }^{5}$ Only in the 1950s, at the same time as the "school wars" took place in Belgium, did the colonial church-state alliance start to fall apart, as the Minister of the Colonies challenged Catholic dominance in the education sector (Boyle 1995).
} 
set up, staffed and ran practically all schools accessible to indigenous people, except schools of military institutions (Boyle 1995). The government dictated teaching programmes and other guidelines, and subsidized many schools. Concession companies influenced the government in articulating education policy, and funded schools for employees and their children, which were run by Catholic missions.

The early period was characterized by pioneering work often done by English-speaking Protestant missionaries, while Catholic missions gained terrain under King Leopold's rule (1885-1908). Leopold II was bound to provide free access to foreign - including Protestant - missions, since this was one of the conditions to retain the special status of the Congo Free State as his personal property. In this respect, the Congo differed from other Catholic colonial territories (French, Spanish and Portuguese), where Protestant missions were banned (Gallego and Woodberry 2010). However, the king of Belgium backed the spread of Belgian Catholic missions by granting them perpetual land grants and government subsidies, for fear of excessive foreign influence. ${ }^{6}$ The subsidy program for the Catholic mission schools was formalized for the first time in an agreement between the Vatican and the Congo Free State in $1906^{7}$ and again under Belgian colonial rule (1908-1960) in 1924 (Harris 1946). In exchange for land concessions and subsidies, the missions ran almost the entire school system in the colony. Belgian colonial officials relied on missions because they were interested in a wide spread of elementary schooling to the masses. This contrasts, for instance, with the French colonial education system, which was nationalized and laicised, and placed more emphasis on the quality of education, but reached fewer people. The territory was divided into ecclesiastical regions assigned to different Catholic congregations, as pictured in Figure 1. Thereby, the area of operation of the UMHK had been assigned to Benedictines and Salesians.

\footnotetext{
${ }^{6}$ By 1943, 3,873 missionaries lived in the Congo of which 3,064 were Catholic and 809 were Protestant; more than three quarters of all pupils attended Catholic schools.

${ }^{7}$ The agreement signed on May $6^{\text {th }} 1906$ stated that each Catholic mission post was to be granted at least 100 hectares of arable land, provided the following four conditions were met: 1) Each post agrees to establish "if possible" a school in which indigenous children are to receive elementary and manual instruction. 2) The curriculum will be submitted to the Governor General and the subjects will be fixed by mutual agreement. 3) Apart from elementary instruction, the curriculum comprises instruction in agriculture, in forestry, and in the manual crafts. 4) Teaching the Belgian national languages will be an essential part of the curriculum (Fabian 1983). The fourth condition was not implemented.
} 
Figure 1 Map of the catholic missions in Belgian Congo, 1923

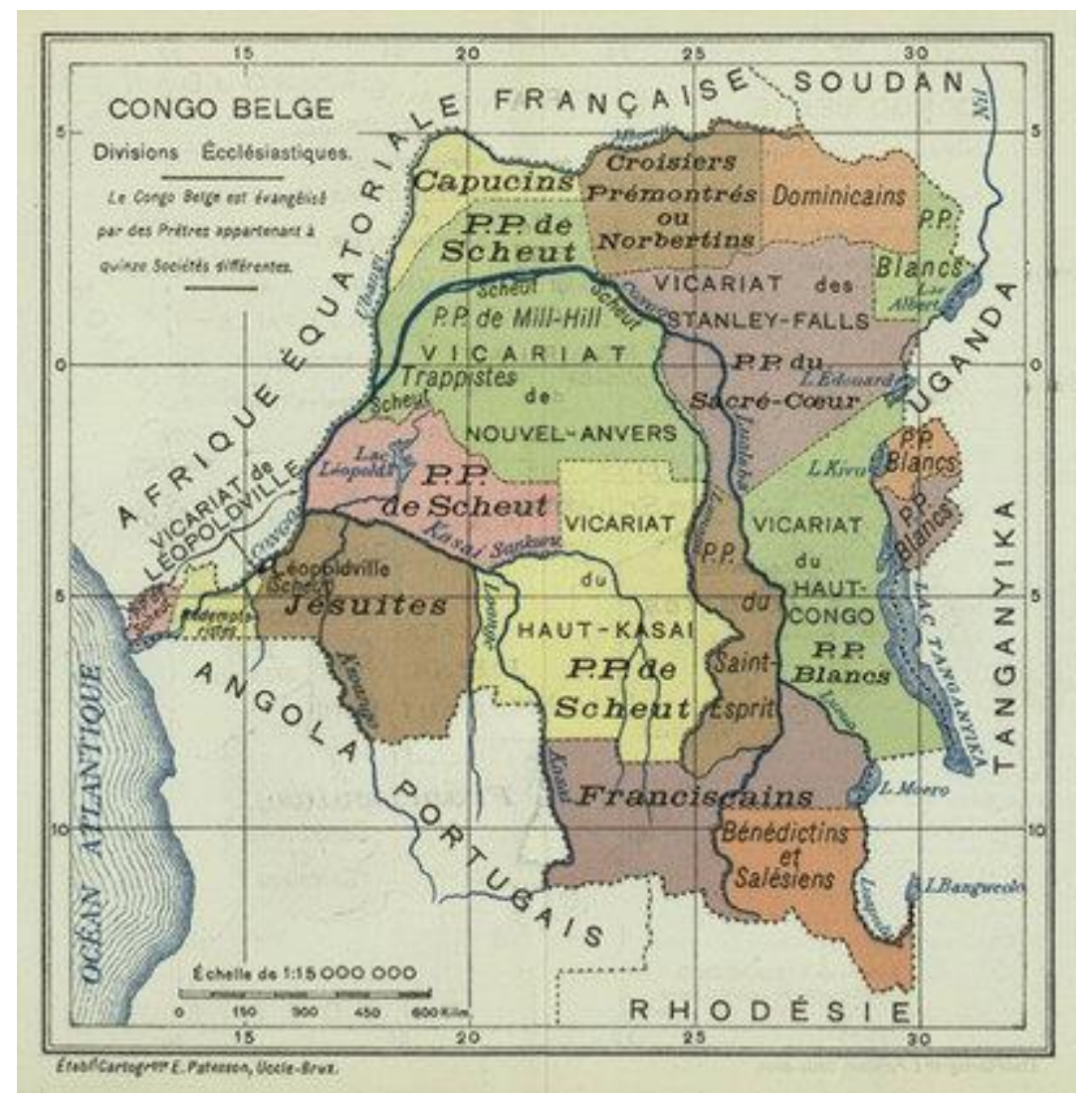

Source: State Archives of Belgium, Records of Hippolyte d'Ursel, no. R27, Map of the catholic missions in Belgian Congo, 1923, accessed 19.06.2018,

<http://www.expocongo.be/content.php? $\mathrm{m}=6 \& \mathrm{r}=3 \& \mathrm{sr}=4 \& \mathrm{doc}=113 \& \mathrm{l}=\mathrm{en}>$

The state soon felt the need to exercise some control over education and entrusted a Commission to design the 1924 education plan ("Projet d'Organisation de l'Enseignement libre au Congo Belge avec le concours des Sociétés de Missions nationales" $\left.{ }^{\prime}\right)$. The purpose of formal schooling in the Belgian Congo, as posited in this document, was to "educate" more than "instruct" the population, to inculcate work ethic and diligence. ${ }^{9}$ The new project sought to introduce a certain degree of standardization in the structure and content of education. Emphasis was placed on the spread of primary schooling, with only minimal opportunities for secondary schooling or professional training. The professional schools trained Africans for jobs that met the needs of the colonial economy and polity, and could not be fully occupied by Europeans: primary school teachers, lower-rank clerks, some medical assistants and craftsmen. Apart

\footnotetext{
${ }^{8}$ The definitive plan was not published until 1929 however, partly because Catholic missions refused to be inspected by the state (Depaepe 2011).

${ }^{9}$ This purpose was re-confirmed in 1948. The Belgian Parliamentary Session documents of 1948 state: "Le premier principe sera d'orienter, plus que par le passé, l'indigène vers l'enseignement technique, plus que vers une formation très vaguement intellectuelle" (Document Parlemantaire du Senat, Z.1947-48, nr. 340, p. 63).
} 
from that, Catholic "sisters" (as female Catholic missionaries were called) and the colonial government offered domestic education for married women (Hunt 1990).

Only very basic literacy and arithmetic were taught in primary schools, and much emphasis was placed on manual work, especially on agricultural training. In the rural areas, children would work the land plot assigned to them during school hours. Primary schooling was imparted in the vernacular languages (mainly in the linguae francae Kikongo, Tsjiluba, Kiswahili, and Lingala), although after the Second World War, French began to gain some popularity. This was different from the French colonies, where French was the only language of instruction (White 1996). Christian missions in the Congo had traced vocabularies and grammar rules of the main vernaculars and translated the bible. They also printed textbooks for students and small booklets for African consumption - and thus, the establishment of print shops and presses became an important aspect of missionary activities. African moniteurs or village teachers, trained in the missionary normal schools, became indispensable for the spread of primary education and they soon outnumbered European instructors.

A limited number of "official schools", which were run by Catholic missions and mostly located in urban centres, were fully financed by the colonial government, while a large number of certified Belgian national mission schools received subsidies. In 1930, less than $5 \%$ of pupils recorded in official government statistics went to official schools, the rest to subsidized schools (see Appendix B). The certified schools had to follow the teaching program dictated by the state and were subject to inspection. "Foreign" mission schools (mostly Protestant) imparted education to a substantial amount of children, but were not subsidized by the colonial government or inspected until 1947, and the number of pupils was rarely recorded in official education statistics.

The school system was organized as follows: the first degree of elementary education was to be provided to as many children as possible; it usually involved two years of attendance. The large majority of Africans did not go further than the "first degree". The second degree of primary schooling (preprofessional) took another three years and was addressed mostly at those children who would continue with the professional training. Professional training prepared a) primary teachers, b) clerk candidates (book keepers, typists, custom house officers, native court registrars, etc.) and c) artisans (carpenters, smiths, wood-workers and printers). The professional training lasted for two to four years. Secondary schools were introduced only in 1949 , under a new school reform ${ }^{10}$ (Masandi 2004). The first university

\footnotetext{
${ }^{10}$ Under the Plan décennal pour le développement économique et social du Congo Belge/ Tienjarenplan voor de economische en sociale ontwikkeling van Belgisch Kongo 1949, the education system was slightly reformed. Two separate education streams were introduced after the first degree of primary school: one for the elite, one for the masses. The structure was changed to: 1 ) Primary $1^{\text {st }}$ degree for everyone ( 2 years). 2) Primary $2^{\text {nd }}$ degree for the masses ( 3 years); or primary $2^{\text {nd }}$ degree for the elite that would continue to secondary (4 years). 3 ) Special training/post-primary for the masses (1-3 years); or secondary for the élite (4-6 years) - either specialized or general. 4) Superior education for the élite (4 years).
} 
of the Congo, Université de Lovanium, was created by the Catholic Church six years before independence, in 1954.

Parents were more hesitant to send their daughters to school than their sons. The 1924 education plan raised concerns about the low female enrolment and posited that more girls' schools ought to be built. In 1930 , only $8.6 \%$ of all primary students were girls; in 1946, the share of girls was $9.4 \% .{ }^{11}$ At independence, no woman was among the hundreds of Congolese with secondary school diplomas or, obviously, among those with superior or university education. The reason may have been a lack of demand, since female education did not lead to significant economic or social advantages, because women were practically excluded from the colonial wage labour market (Masandi 2004). The few remunerated positions they occupied were lower ranks in the education sector. At school, girls were mostly trained to become good housewives to the new indigenous elite. However, the neglect of girls is also in line with the claim of Nunn (2012) that Catholic missions in Africa placed less importance on female education than Protestant missions.

Clearly, the major deficiencies of the Belgian colonial school system were that women were almost excluded from formal education and that the level of education in general was very basic. Beyondprimary education was very underdeveloped in comparison with other colonies, such as the Dutch East Indies (Frankema 2013). As a consequence, by the eve of Congolese independence in June 1960, the aspiring nation had only sixteen African university graduates out of a population of more than thirteen million (Buelens and Cassimon 2013). According to Buelens and Cassimon (2013), the Congo also lacked sufficient human capital to keep the mining sector going after independence, as bars on higher education for Africans in colonial times had seriously limited supplies of high skilled workers.

However, the relative success of the education system in the Belgian Congo in reaching the masses is evident from an international comparative perspective. The Belgian Congo was one of the few African colonies where gross primary school enrolment rates were over 20 percent on the eve of World War II. Colonies with similar enrolment rates were British African colonies such as Northern and Southern Rhodesia, Nyasaland and Uganda. They were higher than the British African average and much higher than the French or Portuguese African averages (Frankema 2012).

After independence, formal education continued to be in the hands of religious orders and subsidized by the state. Only for a short time between 1974 and 1977 did Mobutu's regime nationalize all religious schools in an attempt to found an "integral state". Subsidies were heavily cut after the implementation of structural adjustment programmes in 1986, but in the privatized school system that emerged

\footnotetext{
${ }^{11}$ In 1930, 122,511 boys were enrolled in subsidized and official schools and only 11,513 girls. In 1946, 333,520 boys and 34,672 girls were enrolled in total (Annual Report of the administration of the Colony of Belgian Congo, 1930 and 1946).
} 
enrolment continued to rise (Titeca and De Herdt 2011). Congo's education levels are still above the Sub-Saharan African average (World Bank 2015, p. 27).

\section{Empirical Evidence}

\subsection{Development of school enrolment in the Congo}

This section provides empirical evidence on the development of school enrolment since early colonial times. Furthermore, it shows the regional differences in enrolment across the Congo territory. This prepares the ground to explain the advantage of the more industrialized provinces, particularly Katanga. The colonial sources used for this exercise are the Annual Reports of the administration of the Colony of Belgian Congo, 1920 to $1958 .{ }^{12}$ We derive the number of indigenous children enrolled in the school from the section on education, which reports the number of schools and students of each missionary congregation, and the population numbers from the demographic section. For the post-colonial era we use the population census of 1984 .

The spread of missionary activity in the 1920s was huge, especially after the government formalized guidelines and premises for receiving subsidies in the education plan of 1924. For the years 1920 to 1930 we only know the number of students enrolled in subsidized schools. During this time gross enrolment in subsidized schools rose from 20,000 to 130,000 (see Figure 2 and Table 1). The total number of students enrolled in schools rose again 4.1-fold between 1930 and the end of colonial rule. The share of children enrolled in schools that were subsidized by the state was around $30 \%$ of total students in the 1930s, but increased thereafter and surpassed the share enrolled in non-subsidized entities in 1950. Figure 2 includes all pupils enrolled in primary and post primary schooling, whereby the share enrolled in post-primary was only between less than one and two percent of the total throughout colonial times (see Appendix B). By 1984, total school enrolment had risen to 6,908,300; another 4.5-fold increase since 1958.

\footnotetext{
${ }^{12}$ The colonial government collected education statistics from 1920, but did so more consistently since 1930 (see also Frankema 2013).
} 
Figure 2 Number of students enrolled in primary, secondary and professional education

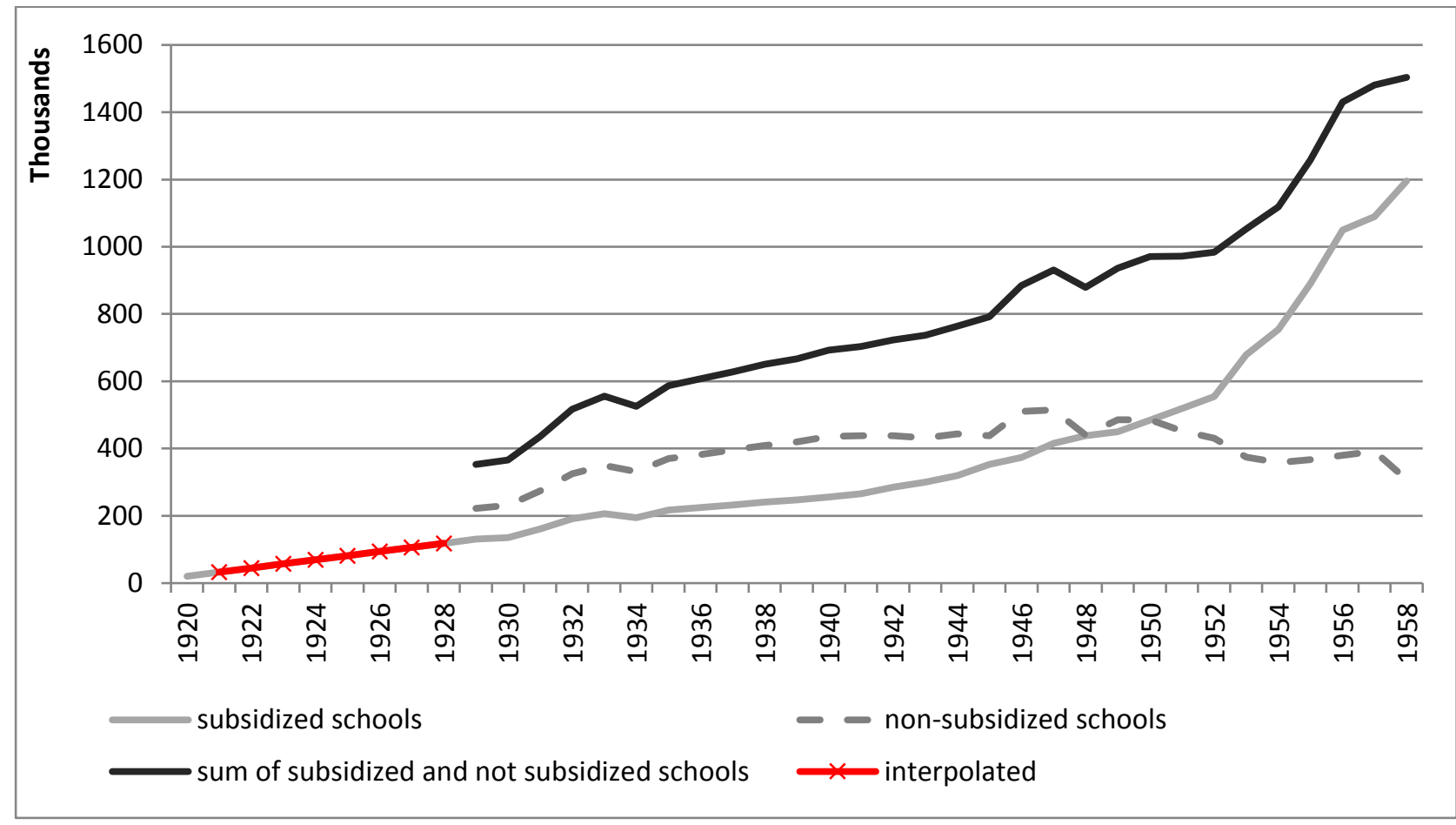

Sources: Annual Reports of the administration of the Colony of Belgian Congo, 1920 to 1958. Note: the number of children enrolled in non-subsidized schools between 1920 and 1929 is interpolated.

The rise in pupil numbers (around 4-fold between 1930 and 1958) by far exceeds demographic growth, which implies improvement in enrolment rates. Total population and the number of children did not even double between 1930 and 1958 (see Table 1).

Table 1 Demographic growth in the Belgian Congo

\begin{tabular}{|l|l|l|l|l|l|l|}
\hline Year & Total pop. & Index & Children & Index & $\begin{array}{l}\text { Number of } \\
\text { pupils }\end{array}$ & Index \\
\hline 1920 & $7,152,808$ & 81 & $1,616,194$ & 50 & $20,314^{*}$ & 6 \\
\hline 1930 & $8,880,872$ & 100 & $3,239,722$ & 100 & 366,358 & 100 \\
\hline 1940 & $10,327,409$ & 116 & $4,129,248$ & 127 & 692,221 & 189 \\
\hline 1950 & $11,268,079$ & 127 & $4,582,294$ & 141 & 970,372 & 265 \\
\hline 1958 & $13,579,138$ & 153 & $6,061,886$ & 187 & $1,503,589$ & 410 \\
\hline 1984 & $30,731,000$ & 346 & $16,123,600$ & 498 & $6,908,300$ & 1,886 \\
\hline
\end{tabular}

Sources: Annual Reports of the administration of the Colony of Belgian Congo, 1920, 1930, 1940, 1950 and 1958 ; and population census of 1984 .

* Includes only pupils enrolled in subsidized schools. 


\subsection{Regional differences in formal education}

Enrolment was not equally spread across the territory. The annual reports allow us to quantify the number of children (generally only boys) enrolled in subsidized schools by province for a few benchmark years (for a map showing the location of the provinces, see Appendix $\mathrm{A}^{13}$ ). If we divide the number of male pupils in a province by the number of boys in the population, we get the enrolment rates shown in Table 2.

Table 2 Primary school enrolment rate boys (percentage of male students to total population of boys), selected years

\begin{tabular}{|l|r|r|r|}
\hline \multirow{2}{*}{ Province } & \multicolumn{3}{|c|}{ Enrolment rate (\%) } \\
\cline { 2 - 4 } & $\mathbf{1 9 3 0}$ & $\mathbf{1 9 3 5}$ & $\mathbf{1 9 4 6}$ \\
\hline Katanga & 16.7 & 22.5 & 27.3 \\
\hline Kasai & 8.1 & 12.8 & 16.8 \\
\hline Orientale & 7.0 & 12.9 & 15.9 \\
\hline Leopoldville & & 6.9 & 15.4 \\
\hline Equateur & & 4.7 & 10.3 \\
\hline Kivu & & 2.5 & 6.5 \\
\hline Total Congo & 8.9 & 9.9 & 15.8 \\
\hline
\end{tabular}

Sources: Author's own calculations. Data from Annual Reports of the administration of the Colony of Belgian Congo, 1930, 1935 and 1946. Note: until 1930, the territory was divided into four provinces, Katanga, Orientale, Congo-Kasai and Equateur, but the latter did not record statistics on student numbers. Results remain similar if we assume school-age population to be $20 \%$ of the total population (see Appendix C).

The differences between provinces are remarkable. The province of Katanga has by far the highest enrolment rates: almost double the average in all three benchmark years. In 1930, Katanga is followed by Kasai and Orientale province, with similar enrolment rates. In 1935, when the provinces of Kivu, Leopoldville and Equateur are added, Katanga still performs best and Kivu and Equateur worst. Interestingly, in the province of Leopoldville, where the capital is located, enrolment is still below average. By 1946, Kivu continues to lag far behind, and Katanga to perform best.

However, we should note upfront that the data need to be interpreted with caution, especially the numbers in the denominator, the total population of boys. First of all, we use the total number of boys of all ages, instead of only school-age children (e.g. 6 to 11), because the latter is not available. ${ }^{14}$

\footnotetext{
${ }^{13}$ We use the province and district names and boundaries of 1947 to 1963.

${ }^{14}$ However, as a robustness check, in Appendix $\mathrm{C}$ we assume the school age population to be $20 \%$ of the total population, like Cogneau and Moradi (2014).
} 
Furthermore, it is well-known that population statistics in colonial times are very inaccurate (Frankema and Jerven 2014). Undercounting of the number of children is expected to occur, especially in those provinces with lower official European presence. In that vein, Katanga should rank among the most accurate statistics, given that the UMHK company operated in large parts of the territory and had tight control over its population. If undercounting occurred in other provinces, then the difference in enrolment rates between Katanga and the rest would in reality be even larger.

On the other hand, the numbers of pupils attending subsidized schools, the numerator, should be relatively reliable everywhere; numbers were provided by school inspectors or missions running the schools. However, the regional statistics include only students enrolled in subsidized schools, which on a country average is between one third and one half of total pupils (see Figure 2). We thus must assume that enrolment in subsidized schools as a share of total enrolment (in subsidized and non-subsidized schools) is more or less equal in all provinces, or else interpret the figures as enrolment in subsidized schools only. Those schools that are funded by private companies are excluded as well. In that vein, the figures can most certainly tell us something about differences between provinces but not actual enrolment rates.

The regional differences in enrolment are probably a reflection of the demand for skilled labour. The missionaries thus set up schools not (only) where geographical conditions were favourable, but where the industry had demand for labour. The UMHK mining company operated in the Haut Katanga district of the Katanga province, which hosts a large part of the "Copperbelt"15. If we zoom further in, the Haut Katanga district has an even higher enrolment rate than the Katanga province as a whole. In the year 1935, enrolment in Haut Katanga district is $53.9 \%$ whereas in the entire province it is $22.5 \%$. This company had a huge demand for labour and this labour needed at least some basic skills, as will be discussed in detail in section 4.

The province with the next largest enrolment rate was Kasai, where another large semiprivate mining company operated: Forminière. ${ }^{16}$ From the beginning of diamond exploitation in 1912, the state and Forminière collaborated to assure a dependable supply of labour. Together they formulated and enforced policies on recruitment, wages, food production, housing, medical care, education, and other services. Its labour policies and living conditions in camps were similar to those at the UMHK, but slightly different at the same time. Forminière had a large population to draw labour from in the surroundings

\footnotetext{
${ }^{15}$ The so-called Copperbelt is a mountainous mineral-rich strip of land at the border between the Congo and Zambia.

${ }^{16}$ Société Internationale Forestière et Minière (Forminière) was one of the three companies created by Leopold II in 1906, besides UMHK and Compagnie du Chemin de Fer du Bas-Congo au Katanga (BCK). Extraction increased from a few thousand carats in 1913 to 200,000 carats in 1918, and at the eve of World War II, 60\% of world's diamonds were produced in the Congo. All the production was managed, if not owned, by Forminière. Between 1921 and 1924 the Forminière workforce jumped from ten to twenty thousand, making it the largest employer of the Congo until World War II (Derksen 1983).
} 
of the diamond deposits. Together with the short-term nature of the mining operations at any one site, this permitted the introduction of more casual, rather than stabilized contract labour. ${ }^{17}$ Still, from the mid-1920s the company adopted the policy of stabilizing part of its workforce. In 1925, it opened a training school at Tshikapa for masons, carpenters, woodworkers, blacksmiths, fitters, drivers, and nurses. In the 1930s, it continued its stabilization program by creating primary schools. The first primary school for boys opened at Tshikapa in 1931. It was staffed by Scheut Fathers through an agreement very similar to one that existed between Union Minière and the Benedictine Order in Katanga (Derksen 1983).

Other large concerns ${ }^{18}$ - employing less labour than the UMHK and Forminière - that offered primary education and professional training in cooperation with missions were: Les Huileries du Congo Belge ${ }^{19}$ (palm oil plantations in Équateur, Orientale and Léopoldville Province), Géomines (tin and cassiterite mining in the district of Haut Lualuba in Katanga), La Compagnie Minière des Grands Lacs and Société des Mines d'Or de Kilo-Moto (gold mining in Orientale province), as well as Les Sociétés Minières et de Transport in Katanga ${ }^{20}$ (Annual Report of the administration of the Colony of Belgian Congo, 19391945). None of them operated in Kivu, the most remote province, dominated by smallholders and some European settler agriculture - mainly coffee and dairy products - as well as small-scale mining (mainly gold).

Figure 3 shows the correlation between school enrolment in colonial times on the one hand and the share of male wage workers engaged outside agriculture (in industry, mining, construction, transport, etc.) on the other hand. There is a positive correlation, especially for the year 1935. Katanga stands out as a substantial positive outlier, especially in 1965 . The major negative outlier is Kivu, with a relatively high share of the wage labour engaged in mining but very low school enrolment rates. Mining in Kivu was not in the hands of companies (even today, most of the mining that takes place in this province is artisanal, often informal, mining), and could be carried out by unskilled subsistence miners. Thus, investments in education failed to materialize there.

\footnotetext{
${ }^{17}$ Until the late 1910s most of the workforce was also voluntary, but this changed since voluntary labour did not keep up with the rise in production. In 1921, the Bourse du Travail du Kasai was established, and it operated under similar conditions as its Katangese counterpart (Derksen 1983).

${ }^{18}$ For a comprehensive list of companies operating in the Belgian Congo, see Buelens (2007).

${ }^{19} \mathrm{HCB}$ was a British financed company - founded by Lever Brothers Ltd., a soap producer - that was granted a concession over 750,000 hectares, the equivalent of one quarter of the Congo territory, in 1911. In the contract with the colonial state, the company committed itself to finance at least one doctor, a clinic and a school in each of the five concession areas (Nicolaï 2013, p. 5). By 1960, the HBC funded 75 primary schools, two secondary and several technical training centres (ibid, p.8). However, the palm oil companies are also famous for their coercive labour and forced recruitment practices, especially during the interwar period. The international export of palm oil produced in Congo reached its apex in the 1950s and started to decline after 1960.

${ }^{20}$ These include Chemin de Fer du Katanga (CFK), Chemins de Fer Léopoldville-Katanga-Dilolo (LKD) and Chemins de Fer du Bas-Congo au Katanga (BCK) (Buelens 2007).
} 
Figure 3 Correlation between school enrolment and share of wage workers engaged outside agriculture, 1935 and 1946

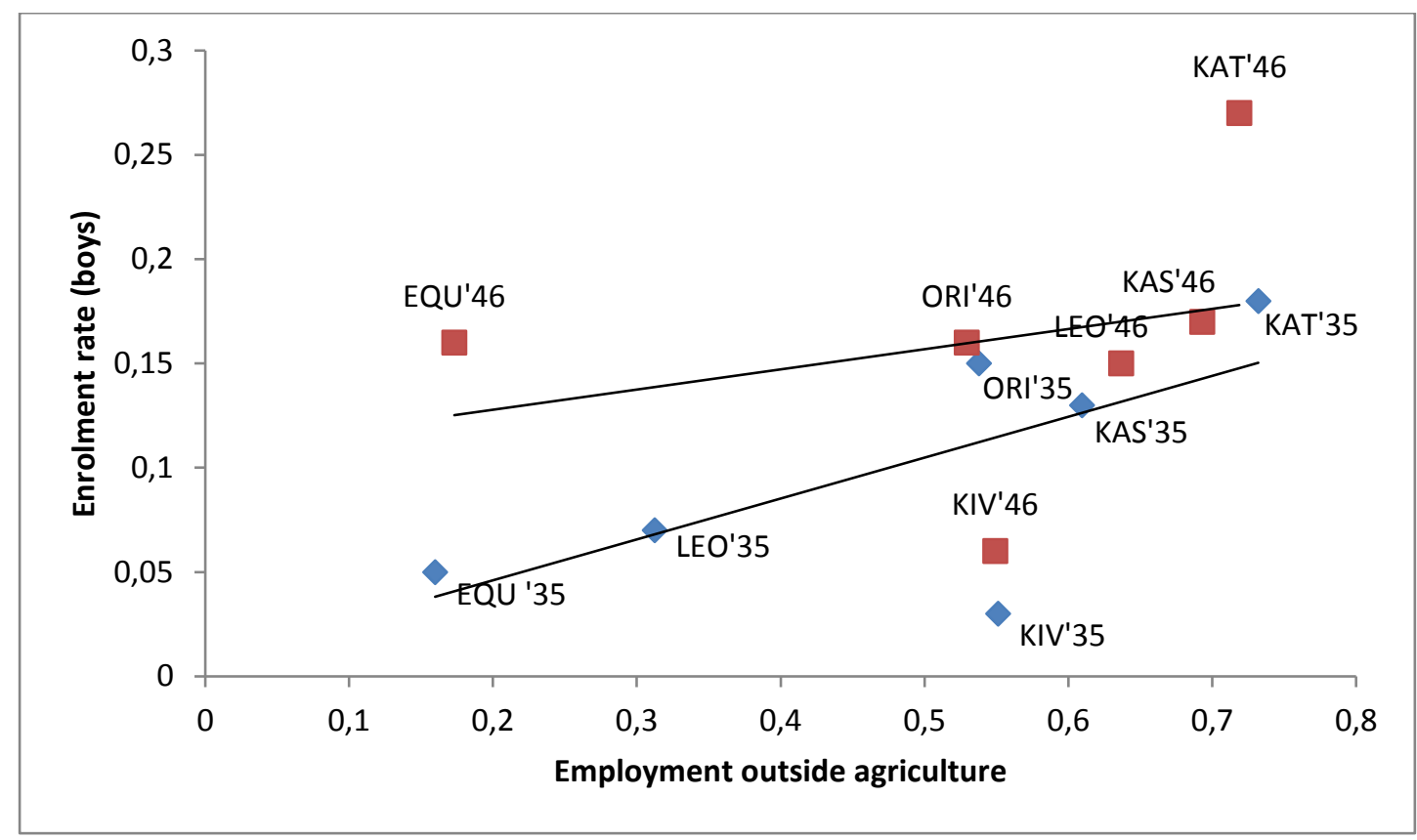

Sources: Annual Reports of the administration of the Colony of Belgian Congo, 1935 and 1946. The two lines are trend lines for 1935 and 1946 respectively.

We can show the relative persistence of educational inequality between regions by comparing colonial and postcolonial education statistics. A special report on women, carried out in the framework of the population census of 1984, allows us to portray women's enrolment and illiteracy in the provinces of the Congo (Table 3). These enrolment rates are not directly comparable with those portrayed in Table 3 for colonial times, both due to the issues concerning colonial population and enrolment data mentioned above and because Table 3 refers only to women. ${ }^{21}$ However, they serve to compare the rank of provinces in educational performance. Leopoldville (which hosts the capital city) displays now by relatively far the highest enrolment and lowest illiteracy rates ( $41.8 \%$ and $42.4 \%$ respectively). This has changed with respect to colonial times, when Katanga displayed the highest enrolment rates. Probably, after independence, the capital city of Kinshasa attracted more educated workers, who also took over higher administrative ranks that had previously been reserved for Europeans. The capital city may also have been ahead of other regions in terms of gender equality in education and labour market participation, for instance if more service sector jobs emerged there, since those are generally more prone to be filled by women than are jobs in industries like mining. Plus, due to the collapse of the mining industry of Katanga from the 1970s, the demand for skilled mining labour may have dropped

\footnotetext{
${ }^{21}$ Unfortunately, no education data on province level are available for the total (male and female) population.
} 
there. However, Katanga and Kasai follow directly after Leopoldville - they perform similarly and better than the average of the Congo. Kivu and Equateur continue to perform worst in terms of enrolment (and literacy), as was the case in 1935 and 1946.

Table 3 School enrolment (age 5-29) and illiteracy (all ages) of women, 1984

\begin{tabular}{|c|c|c|c|}
\hline Province(s) of 1984 & Province of 1950 & $\begin{array}{l}\text { enrolment } \\
(\%)\end{array}$ & $\begin{array}{l}\text { illiteracy } \\
(\%)\end{array}$ \\
\hline $\begin{array}{l}\text { Bandundu, Kinshasa, Bas } \\
\text { Zaire }\end{array}$ & Leopoldville & 41.8 & 42.3 \\
\hline Shaba & Katanga & 34.7 & 49.1 \\
\hline $\begin{array}{l}\text { Kasai Occidental, Kasai } \\
\text { Orientale }\end{array}$ & Kasai & 34.4 & 46.7 \\
\hline Haut Zaire & Orientale & 25.4 & 61.2 \\
\hline Equateur & Equateur & 24.7 & 68.9 \\
\hline $\begin{array}{l}\text { Maniema, Nord-Kivu, Sud- } \\
\text { Kivu }\end{array}$ & Kivu & 21.5 & 69.5 \\
\hline Total Congo (Zaire) & Total Congo & 32.3 & 54.6 \\
\hline
\end{tabular}

Source: Recensement scientifique de la population, 1984: profil de la femme au Zaïre.

Note: province boundaries of 1984 were harmonized with those of 1950 (enrolment and literacy weighted by the population of 1984 provinces were combined into 1950 provinces)

The coming section will deal with the labour policies of the UMHK, providing an example of how the industry contributed to the spread of schooling.

\section{UMHK labour policies and education}

The UMHK was founded in 1906 and the first copper was produced in 1912, two years after the railways reached Elisabethville and connected the mines to the port of Beira in Mozambique, from where the product was exported (Fetter 1976). The UMHK company retained a government-backed monopoly on copper mining in Katanga throughout colonial times and the state had a ca. $60 \%$ stake in the company until copper was nationalized entirely by Mobutu in 1967.

Since its emergence, the copper mining industry of Katanga had been the backbone of the Congolese economy. Copper exports accounted for a large share of total exports and the government was heavily dependent on revenues from copper. For instance, in 1936, sixty-seven percent of the total export value of the colony consisted of mining products. On the eve of independence in 1960, copper produced in the Katanga province (around 320,000 tons) accounted for $45 \%$ of total export value, and $8 \%$ of total world production (Juif and Frankema 2018). The copper mining industry also employed large numbers of 
workers and turned the once sparsely populated area of the Copperbelt into one of the most urbanized ones in Central Africa. Between 20,000 and 30,000 indigenous workers were employed by the UMHK at any time of the year from the 1920s to 1950s (except for a slump in the early 1930s due to the Great Depression). The company was the largest employer in the Congo for most of the colonial period.

\subsection{Towards stabilization at UMHK}

Labour scarcity was a problem throughout colonial times, especially before the Great Depression. In the early $20^{\text {th }}$ century, the area of the Copperbelt was sparsely populated and the population had little incentives to engage in mining labour. Working for Europeans had a bad reputation in the Congo given the atrocities committed during the exploitation of rubber under King Leopold II. Moreover, morbidity and mortality among mining workers were very high, and the mining industry had opened up possibilities for supplying the mines with agricultural products, which was more attractive than wage labour in the mines.

Until the mid-1920s, the company relied mainly on forced recruitment from distant areas to meet its manpower needs. In 1910 a parastatal labour recruiting agency, the Bourse du Travail du Katanga (BTK, later OCTK), was formed by the colonial government. Other private recruiters, such as Robert Williams' Tanganyka Concessions Limited and the Portuguese Correa Freres, were competitors of the BTK, although they hunted mainly outside the Belgian Congo for labourers. ${ }^{22}$ Recruitment did not always occur on a voluntary basis. In the Belgian territories it was carried out in cooperation with the colonial government and local chiefs. BTK employees were often accompanied by the military in their recruitment missions. The government set quotas on the percentage of men that could be recruited in each village, but these were often surpassed. The state also assisted the industry by raising taxes that pushed the population into the wage labour market. Furthermore, it introduced an identification system to trace defaulting workers and in 1922 legalized the use of physical violence to force workers to fulfil their labour contracts (Perrings 1979, Houben and Seibert 2013).

The UMHK absorbed most available indigenous wage labour in Katanga province, and the remaining workers came from the central Congolese province of Kasai, the Belgian protectorate of Rwanda (since 1924), the British Rhodesias and Nyasaland, and Portuguese Angola. Until 1925, the company was highly dependent on labour from Northern Rhodesia (from where more than $40 \%$ of indigenous workers originated). However, in 1925, the Northern Rhodesian colonial government gave in to pressure from the nascent Rhodesian mining industry, which needed indigenous labourers itself, and set limits to

\footnotetext{
${ }^{22}$ Other indigenous people crossed the Northern Rhodesian border on their own initiative, attracted by the lure of cash wages and urban life.
} 
emigration to Katanga. Consequently, the share of Rhodesians in Katanga declined sharply and, in 1931, the UMHK decided to stop recruiting altogether outside Belgian territories (Fetter 1976).

In the 1910s and early 1920s, most of the workforce consisted of casual labourers who worked on contracts of three to six months. They engaged in mine work in open pit mines - often digging with their bare hands - and acted as domestic servants and human carriers. They also dug ditches, and built the rail lines and foundations of buildings. There was only a small component of permanent skilled labour in the foundry in Elisabethville and in the Star of the Congo mine, who came mostly from Nyasaland and the two Rhodesias.

After the First World War, the value of the Belgian franc against the British pound dropped precipitously (see Appendix D), so that the skilled white labour paid in sterling (as well as indigenous labour from British colonies) became increasingly expensive. During the 1920s, the company invested heavily in mechanization in order to save labour costs. This increased the need of the company for more educated workers from Belgian territories, who could handle the machines and be paid in francs.

From 1925, the policy of stabilization, i.e. of binding workers for as long as possible to their employer, was made explicit. The main motive was to save expenses on white workers' wages and on indigenous labour recruitment, and to avoid a high turnover. ${ }^{23}$ The company started to make long-term investments in workers' and their offspring's skills and health. These benefits in turn made workers more content and more likely to engage for another contract.

For the purpose of stabilization, only three-year contracts were given after 1927 (before, most engaged in 6 months-contracts). While in 1928, $45 \%$ of the workforce had a contract for the duration of three years, 98\% had one in 1931 (De Meulder 1996). As of 1923 workers were allowed to bring their wives to the compounds as well. Soon, the company realized that married workers were healthier, more content and therefore more productive. They were also more likely to settle for a longer time or indefinitely in the camps. Thus, families were actively attracted, and the company even advanced the bride-price to future workers so that they could marry before starting their contracts (Fetter 1976). ${ }^{24}$ The UMHK provided special housing for married workers as well as extra rations and bonuses in cash. The amount of women and natality skyrocketed, as shown in Table 4 . The number of children per woman living in the camps rose slowly from 1.5 in 1926 to 3.9 in 1965.

\footnotetext{
${ }^{23}$ The costs of recruitment were high and involved transportation, food, clothes and medical care during the journey to the mines, as well as recruitment fees. Also, several far-away recruited workers were lost to mortality, morbidity or desertion during the journey, or upon arrival at the mines due to their failure to adapt to the work or climate. High labour turn-over was expensive because new employees had to receive training, health checks and vaccinations.

${ }^{24}$ Of course, only monogamous families were attracted and only one wife was provided with family benefits, although polygamy was not uncommon in the Belgian Congo. The average household size in the camps increased from 2.8 in 1946 to 3.3 in 1951 to 4.7 in 1965 (UMHK M.O.I. Annual Reports).
} 
Table 4 Living conditions of indigenous labour at the UMHK in the 1920s

\begin{tabular}{|l|c|c|c|c|}
\hline Year & $\begin{array}{c}\text { Percentage } \\
\text { married }\end{array}$ & $\begin{array}{c}\text { Average number } \\
\text { of children }\end{array}$ & $\begin{array}{c}\text { Children per 100 } \\
\text { workers }\end{array}$ & $\begin{array}{c}\text { Birth rate per } \\
1,000 \text { inhabitants }\end{array}$ \\
\hline 1924 & 14.8 & & & \\
\hline 1925 & 18.8 & & & \\
\hline 1926 & 22.1 & 940 & 31.9 & 20.0 \\
\hline 1927 & 23.6 & 1,423 & 38.9 & 25.3 \\
\hline 1928 & 30.6 & 2,105 & 44.7 & 30.6 \\
\hline 1929 & 33.71 & 3,149 & 54.1 & 33.4 \\
\hline 1930 & 40.84 & 4,457 & 66.8 & 46.8 \\
\hline
\end{tabular}

Source: 1930 Report of the Health Inspector of Northern Rhodesia on Native Labour in Katanga ${ }^{25}$ (see also Juif and Frankema 2018)

In general, welfare provisions improved dramatically with the policy of stabilization. Children were supposed to be the future generations of workers, educated in the spirit of the company. Catholic missionaries were mostly in charge of health, education and other social services and were backed financially by the company. The department in charge of social services for indigenous workers' families was the O.P.E.N (Oeuvre de protection de l'enfance noir). Mothers and infants up to five years old were encouraged by the O.P.E.N. to visit the infant welfare clinic for medical checks, where they received ration tickets for milk, sugar and soap. When children went to school, from the age of five, they were provided three cooked meals per day at the messes. When women were pregnant, their food rations, provided by the company, were doubled.

In order to save labour costs the UMHK as well as other companies in the Congo successfully replaced white workers with indigenous workers. Between 1930 and 1934, 1,360 Africans took over positions at the UMHK which formerly only Europeans had been considered competent to hold (Harris 1946). The placement of some Africans in relatively skilled positions would not have been tolerated in many surrounding colonies where the "colour bar" prevailed, such as in the Rhodesias and in South Africa (Juif and Frankema 2018, Higginson 1988).

A quarterly report on "Rhodesian Natives in the Katanga" sent by the British Vice Consul in October 1929 stated that "the conditions under which natives work could hardly be bettered as regards feeding, hospitals, housing and general treatment. Conditions have much improved since I arrived here in 1925".

\footnotetext{
${ }^{25}$ Inter-state contracts arranging the engagement of Northern Rhodesian labour in Katanga included the posting of a permanent Inspector of Rhodesian Labour at the largest mine, the "Star of the Congo"/ Lumumbashi (until 1933).
} 
However, according to the historian John Higginson, not all was rosy. Stabilization was intended to tie the labour force to the company and reproduce subsequent generations of African workers at a very low cost, "based upon coercion and racial superiority, and at the expense of political freedom" (Higginson 1989, p. 216). The indigenous were considered to have "souls of children" who had to be disciplined to work and not to desert (see Mottoulle 1946, p. 5: "Le colonisateur ne doit jamais perdre de vue que les nègres ont des âmes d'enfants [...]"). Possibly, if Africans had the option, they would engage in "unbound" work paid in sterling rather than in long-term contracts at the Katanga mines, as De Haas (2016) has shown for Rwandan migrants. Trade unions were forbidden in the Belgian Congo until after World War II, and their influence as well as workers' affiliations to them remained moderate until independence. Missionaries partnered up with state and company management and schooling was used to guide the masses in the desired direction. In history lessons, revolutions were discussed with particular circumspection not to awaken the revolutionary spirit, and textbooks emphasized the power and wealth of the Belgian nation (Van Reybrouck 2005, p. 205; Depaepe 2012, p. 207). The company possibly also recruited pupils before they were deemed to have completed their education (Dunkerley 2009, p. 125).

During the economic hardship of the 1930s (the labour force had been drastically reduced and the average salary declined by $20 \%$ from 1930 to 1934), the UMHK sought to save on food expenses at the same time as continuing to stabilize its workforce. The company had been buying a large share of its food supplies from European farmers in Rhodesia and, after Kasai was connected to the railway in 1927, from commercial companies selling the agricultural produce of Kasaian peasants. From the early 1930s, worker's wives living in the compounds were to grow vegetables like maize, potatoes and groundnuts in their backyards and sell them to the UMHK. Company officials expected them to be willing to sell their produce at fixed prices - around $40 \%$ lower than those paid to European farmers - in order to complement their husbands' low salaries. ${ }^{26}$ The M.O.I. annual report of 1933 (p. 12) states the following concerning the topic:

"Nous avons entrepris en 1933, une propagande intense parmi les populations de nos camps pour l'extension des cultures vivrières. Nous comptons acheter aux femmes de nos travailleurs telle partis de leur récolte de maïs vert, patates, arachides, qu'elles voudraient nous céder. Ces achats se feront, sans difficultés, á des prix d'environ $40 \%$ inférieurs à ceux que nous payons actuellement aux fermiers Européens. Cette politique d'achats de vivres aux femmes de nos travailleurs apporte aux ménages indigènes qui nous sont attachés, des ressources appréciées a une époque où les salaires ont été fortement réduits. Elle a une action bienfaisante sur la stabilisation de la MOI et sur la moralité des camps."

\footnotetext{
${ }^{26}$ Furthermore, the peasant "squatters" living in the outskirts of the cities of Katanga (called centres extracoutumiers after 1931) - many of whom were former miners dismissed by the UMHK because of the economic depression - were to produce food and sell it at fixed prices to the company, to feed mining workers and their families. To tie squatters to cash and the market, a special tax was introduced in the province.
} 
During the Second World War, the general costs of living in Katanga increased and the purchasing power of workers declined slightly (Higginson 1989, p. 180). Although UMHK workers were housed and fed for free, they had developed a taste for a wide range of consumption goods. In 1941 a strike broke out among UMHK indigenous workers demanding an adjustment of wages, and raising other grievances against colonial order. Around 100 strikers were killed at Elisabethville. Paternalism, in the form of the company's stabilization policy, had both its obvious advantages as well as its liabilities. From the workers' point of view, the company should have assumed greater responsibility for their wellbeing, since it had taken away their mobility in the labour market (Higginson 1989, p 182).

After the war, given the success of the industry and the switch in the Belgian policy of colonial exploitation in favour of a more developmental doctrine, wages and living conditions improved. The average real wages of UMHK indigenous workers probably doubled between 1941 and 1950 (Juif and Frankema 2018). The rise in the material living standards of mining workers boosted consumption demand, and spilled over to other local economic sectors (breweries, food processing and cement industries, as well as electric power plants). ${ }^{27}$ Political and trade union freedom was gradually allowed and the segregation policy was abandoned (Buelens and Marysse 2009).

In conclusion it may be said that the policy of labour stabilization followed by the company in cooperation with state and church resulted in a rise in the wellbeing of the indigenous workforce and their families. It provided them with formal education, as well as with better food, housing and health care. On the other hand, it precluded liberties such as trade unionism and the possibility to switch employers. Certainly, it was in the interest of the company, as it made it possible to save on recruitment, and secure a future labour force that had been "educated" by the missionaries to be obedient workers.

\subsection{Education in Katanga}

The children of Union Minière workers were very likely to attend schools. The company aimed to promote formal schooling among children of all their indigenous labourers, so that they could be raised to be the future workforce of the company. Education in UMHK compounds was provided by the Benedictines in Haut Katanga and by Franciscans in Lualuba district (see maps Figure 1 and Appendix A).

The Benedictines arrived in Elisabethville in 1910, and they conducted their work in cooperation with the Salesian Fathers who arrived in the following year (Dunkerley 2009, p. 121). Franciscans only arrived in the district of Lualuba in 1920. Katanga had not been an attractive location for missionaries

\footnotetext{
${ }^{27}$ Industrial companies operating in Katanga were: Breweries (Brasseries du Katanga), construction materials (Societé des Ciments du Katanga), textiles (Texaf, Usines Textiles de Leopoldville), electrical power concerns (Sogefor and Sogelec), and chemical companies (Sogechim).
} 
in earlier times: it was sparsely populated and not well connected by waterways as, for example, the Congo Basin, but with the rise of the mining industry and population growth, the area became attractive as a source of potential converts.

Benedictines and Salesians ran the official schools as well as most subsidized rural schools in the district of Haut Katanga (see Figure 1). There were also two Protestant missions operating in the area: Mission Méthodiste du Sud-Congo and the Garanganze Evangelical Mission (Johnson 1967, p. 181), and as of 1931 the Catholic Xaverians also ran a few subsidized schools. The Catholic "Sisters of Love" and the Benedictine Sisters were in charge of female education.

In 1926, when the policy of stabilization became explicit, the UMHK entered a partnership with the Benedictines under the terms of which the company funded schools where the missionaries would educate the children of workers (Dunkerley 2009, p. 124). ${ }^{28}$ Miners were however allowed to send their children to Protestant mission schools if they preferred. In 1931, the UMHK financed schools in their seven main mining camps (Lumumbashi, Kipushi, Panda, central workplace, Kambove, Kontwe, Shinkolobwe) with in total 904 pupils (Annual Report of the Administration of the Colony of Belgian Congo, 1931, p. 194). The railway company of Katanga financed another school with 42 pupils. In 1935, 1,194 out of a total of 1,400 children of workers of school age attended schools financed by the UMHK: 674 boys and 520 girls (UMHK M.O.I. annual report 1935). ${ }^{29}$ This figure shows not only that the enrolment rate in the camps was very high (over 80 percent), but also that the share of girls attending school exceeded by far the average in the colony. Primary schooling was actually compulsory and mothers who did not take their children to school were punished by not receiving food rations (Mottoulle ${ }^{30}$ 1946). After the Second World War, enrolment in company schools rose further: in 1949, 8,941 children attended the company schools (UMHK M.O.I. annual report 1949).

However, education was clearly designed to meet the needs of the company, and was combined with manual work that saved expenses on labour and material. There was a strict separation between boys and girls, both physically and in terms of teaching content. Gender segregation was enhanced by the fact that children were educated to fulfil the needs of the industry, since only boys became future company workers (girls became housewives). From the age of 10, while some of them still went to school, boys were engaged by the company in "travaux légèrs", such as cleaning, planting, and cutting trees. The duration of their service rose with age and strength, from a few hours per day for the young children to the whole day for adolescents (from age 12). Girls who went to sewing school from the age of 10 produced clothes for company workers. Adolescents continued to eat at the children's mess and received

\footnotetext{
${ }^{28}$ The situation was very different in the compounds south of the border, in the Rhodesian Coopperbelt, where missionaries were not welcome (Juif and Frankema 2018).

${ }^{29}$ And in 1937, 13 schools for UMHK were run by Benedictines with 1,232 recorded pupils (Dunkerley 2009, p. 124).

${ }^{30}$ Dr. Mottoulle was associate member of the Institut Royal Colonial Belge. He was a consultant for medical issues and labour of both Forminière and UMHK.
} 
a low salary that allowed the company to save labour costs, as pointed out in the indigenous labour reports (UMHK M.O.I. annual report 1935). Young boys from the age of 16 were incorporated into the regular work groups as apprentices. A limited number of boys received training at UMHK professional schools as carpenters, smiths or clerks, and at the UMHK hospital as nurses (Mottoulle 1946). The instructors at professional schools were priests, seconded by African auxiliaries, moniteurs (social assistants) and instituteurs (schoolmasters). Primary school education, on the other hand, was mainly provided by Congolese teachers.

School enrolment among UMHK workers was exceptionally high, but what about the rest of the district? In 1935, the enrolment rate of boys in the Haut Katanga district, where the company operated (pupils visiting UMHK-financed schools and non-subsidized excluded) was much higher, 53.9\% (see Table 5), than on average in the province of Katanga (22.5\%) and, by extension, than the Congo average (9.9\%).

Table 5 Enrolment in Haut Katanga district, 1935

\begin{tabular}{|c|c|c|c|}
\hline Congregation & $\begin{array}{l}\text { Enrolled boys } \\
\text { (subsidized schools) }\end{array}$ & $\begin{array}{l}\text { population of } \\
\text { boys }\end{array}$ & $\begin{array}{l}\text { enrolment } \\
\text { rate }(\%)\end{array}$ \\
\hline Benedictins & 16,307 & \multirow{3}{*}{33,452} & \multirow{3}{*}{53.9} \\
\hline Xaverians & 224 & & \\
\hline Salesians & 1,513 & & \\
\hline
\end{tabular}

Source: Annual report of the administration of the Colony of Belgian Congo, 1935

Clearly, the population that lived closest to the mining industry had incentives and/or opportunities to send their children to school. Not only among the children of mining workers, but also among other children living in the same district where the mining company operated, enrolment rates were exceptionally high. We can derive from this that the industry worked as a catalyst to enrolment. The mining industry itself certainly had incentives to educate workers' children to train their future workforce. However, as a spill-over effect, the population living in the surrounding areas probably chose to send their children to school because they recognized the opportunities of acquiring better paid jobs. As an indirect promoter of education, the mining industry attracted other industries, such as food processing, breweries, etc., which also needed skilled workers.

\section{Conclusion}

The literature on colonial education in Africa so far has focussed on pre-colonial geographic conditions and colonial state attitudes ("laissez-faire" or intervention and laicity) as determinants of the spread of 
Christian missions. It has mainly looked at differences between British and French territories. This study added the case of a Belgian colony and showed the role that industry and state labour policies played in promoting education. It provided a complementary view on the determinants of long-term development of education in Africa, thereby contributing to the literature on the fundamental causes of economic growth.

We traced the development of school enrolment since early colonial times and reported the differences between provinces. Furthermore, we showed the persistence of regional inequality in education into post-colonial times. We then dug deeper into the labour policies of the UMHK, the largest mining company of the colony. The policy of stabilization went hand in hand with large investments in both professional training and primary education. The aim was to curb labour scarcity, to avoid high and expensive labour turnover, and to replace skilled white workers by cheaper indigenous ones. The coordination of industry and state interests while shaping labour policies derived from the colonial state's majority stake in the UMHK and other large companies.

The fact that not only among workers' children, but also in the entire district where the company operated, enrolment was higher than elsewhere suggests that the prospects of a job in the mining industry (or in the industries that arose around the mines) raised incentives for indigenous parents to invest in children's education.

The lessons drawn from the case of the UMHK can be generalized to the rest of the Congo, since labour policies were largely influenced by the Belgian colonial administration, in line with its general paternalistic attitude. In fact, all large companies adopted the policy of stabilization and provided welfare as well as schooling facilities in their compounds from the mid-1920s.

These policies had positive consequences for the population in terms of raising their living standards to serve as a healthy, trained and content workforce. However, the paternalistic ideology undermined political liberties such as trade unionism and voting rights (the first municipal elections open to black voters took place in the largest cities in 1957, only three years before independence). The state could also have performed better in providing post-primary education to at least a limited number of Congolese. The absence of an indigenous intellectual elite, as well as the inadequate preparation of the population as politically mature subjects, certainly hindered the formation of an independent state. However, the demand, by the industry, for large numbers of workers with at least basic skills and the stabilization policy contributed to the spread of elementary school enrolment.

\section{Primary sources:}


Mottoulle, L. (1946). 'Politique sociale de l'Union miniére du Haut-Katanga pour sa main-d'oeuvre indigène et ses résultats au cours de vingt années d'application' (Vol. 14), Brussels: Georges van Campenhout. Accessed 19.06.2018, <http://www.kaowarsom.be/en/memoir_43>

Office de L'information et des relations publiques pour le Congo Belge et le Ruanda-Urundi (1956). 'Cartes géographiques du Congo Belge et du Ruanda-Urundi'. Fourth edition. R.De Rouck Brussels.

'Recensement scientifique de la population, 1984: profil de la femme au Zaïre', Institut national de la statistique (Congo). From Archives Africaines, Brussels.

'Rapports Annuels de L'Administration de la Colonie Congo Belge' / Annual Reports of the administration of the Colony of Belgian Congo, 1920 to 1958. From Archives Africaines, Brussels.

'Rapports Annuels UMHK Département de la M.O.I. (Main-d'œuvre indigène)' I Annual Reports UMHK - Department of Indigenous Labour, 1920 to 1964. From Archives générales du Royaume 2 Dépôt Joseph Cuvelier, 653-659, Brussels.

'Report of the ministry of the colonies', Brussels, year 1919. From Archives Africaines; M.O.I. 3547 (24).

'Tienjarenplan voor de economische en sociale ontwikkeling van Belgisch Kongo 1949'. Brussel Les editions de Visscher. Eerste Boekdee. From Leiden University Africa Archive.

\section{Secondary sources:}

Bolt, J. and Bezemer, D. (2009), 'Understanding Long-Run African Growth: Colonial Institutions or Colonial Education?', Journal of Development Studies, 45(1): 24-54.

Boyle, P. (1995), 'School Wars: Church, State, and the Death of the Congo', The Journal of Modern African Studies, 33(3): 451-468.

Breierova, L. and Duflo, E. (2004), 'The impact of education on fertility and child mortality: Do fathers really matter less than mothers?', National Bureau of Economic Research (No. w10513).

Buelens, F. and Cassimon, D. (2013), The industrialization of the Belgian Congo, in: E. Frankema and F. Buelens (eds.), Colonial Exploitation and Economic Development. The Belgian Congo and the Netherlands Indies Compared, London and New York: Routledge, pp. 229-250 (Ch. 11).

Buelens, F. and Marysse, S. (2009), 'Returns on Investments during the Colonial Era: The Case of the Belgian Congo', The Economic History Review, 62(1): 135-166.

Buelens, F. (2007), Congo 1885-1960: Een Financieel-Economische Geschiedenis, Berchem: EPO

Cogneau, D. (2003), 'Colonisation, School and Development in Africa: An Empirical Analysis', DIAL Working Paper DT/2003/01.

Cogneau, D. and Moradi, A. (2014), 'Borders that divide: Education and religion in Ghana and Togo since colonial times', The Journal of Economic History, 74(03): 694-729.

De Haas, M. (2016), 'African initiative and colonial responses to Ruanda-Urundi migration to Uganda (1920-1960)’, Unpublished Working Paper.

De Herdt, T., Titeca, K., and Wagemakers, I. (2010), 'Making investment in education part of the peace dividend in the DRC', in: Chronic Poverty Research Centre conference 'Ten Years of War againt Poverty', Manchester, UK, September 2010, pp. 8-10. 2010. 
De Herdt, T., Titeca, K., and Wagemakers, I. (2012), 'Make schools, not war? Donors' rewriting of the social contract in the DRC', Development Policy Review, 30(6): 681-701.

De Meulder, B. (1996), De kampen van Kongo: arbeid, kapitaal en rasveredeling in de koloniale planning, Amsterdam: Meulenhoff.

Depaepe, M. (2011), 'Ejes de la Política Educativa Colonial en el Congo Belga (1908-1960) / Axes of the colonial educational policy in the Belgian Congo (1908-1960)', Historia de la Educación, 30: 3344.

Depaepe, M. (2012), Between Educationalization and Appropriation: Selected Writings on the History of Modern Educational Systems, Leuven: Leuven University Press

Derksen, R. (1983), 'Forminière in the Kasai, 1906-1939', African Economic History, 12: 49-65.

Dunkerley, M.E. (2009), Education Policy and the Development of the Colonial State in the Belgian Congo, 1916-1939, PhD thesis, University of Exeter.

Fabian, J. (1983), 'Missions and the colonization of African languages: Developments in the former Belgian Congo', Canadian Journal of African Studies, 17(2): 165-187.

Ferguson, J. (1999), Expectations of modernity: Myths and meanings of urban life on the Zambian Copperbelt, Berkeley CA: University of California Press.

Fetter, B. (1976), The Creation of Elisabethville, 1910-1940, Stanford: Hoover Institution Press.

Frankema, E. (2008), The Historical Evolution of Inequality in Latin America. A Comparative Perspective, 1870-2000, PhD-Thesis, University of Groningen.

Frankema, E. (2012), 'The origins of formal education in sub-Saharan Africa: was British rule more benign?', European Review of Economic History, 16(4): 335-355.

Frankema, E. (2013), 'Colonial Education and Postcolonial Governance in the Congo and Indonesia', in: E. Frankema and F. Buelens (eds.), Colonial Exploitation and Economic Development. The Belgian Congo and the Netherlands Indies Compared, London and New York: Routledge, pp. 153-177 (Ch. 7).

Frankema, E. and Jerven, M. (2014), 'Writing history backwards or sideways: towards a consensus on African population, 1850-2010', The Economic History Review, 67(4): 907-931.

Gallego, F.A. and Woodberry, R. (2010), 'Christian missionaries and education in former African colonies: How competition mattered', Journal of African Economies, 19(3): 294-329.

Galor, O. (2011), Unified growth theory, Princeton: Princeton University Press.

Galor, O., Moav, O., and Vollrath, D. (2009), 'Inequality in Landownership, the Emergence of HumanCapital Promoting Institutions, and the Great Divergence', Review of Economic Studies, 76(1): 143-179.

Garnier, M. and Schafer, M. (2006), 'Educational Model and Expansion of Enrollments in Sub-Saharan Africa', Sociology of Education, 79( 2): 153-75.

Grier, R. M. (1999), 'Colonial Legacies and Economic Growth', Public Choice, 98( 3-4): 317-335.

Harris, J.S. (1946), 'Education in the Belgian Congo', The Journal of Negro Education, 15(3): 410-426.

Higginson, J. (1988), 'Bringing the workers back in: worker protest and popular intervention in Katanga, 1931-1941’, Canadian Journal Of African Studies, 22(2): 199-223. 
Higginson, J. (1989), A Working Class in the Making: Belgian Colonial Labor Policy, Private Enterprise, and the African mineworker, 1907 - 1951, Madison, Wisconsin: The University of Wisconsin Press.

Houben, V. and Seibert, J. (2013), '(Un) freedom: Colonial labor relations in Belgian Congo and the Netherlands Indies Compared', in E. Frankema and F. Buelens (eds.), Colonial Exploitation and Economic Development, London and New York: Routledge, pp. 178-192 (Ch. 8).

Hunt, N.R. (1990), 'Domesticity and Colonialism in Belgian Africa: Usumbura's Foyer Social, 19461960’, Signs, 15(3): 447-474.

Johnson, H.B. (1967), 'The Location of Christian Missions in Africa', Geographical Review, 57(2): 168-202.

Juif, D. and Frankema, E. (2018), 'From Coercion to Compensation: Institutional responses to labour scarcity in the Central African Copperbelt', Journal of Institutional Economics, 14(2), 313-343.

Katzenellenbogen, S.E. (1973), Railways and the copper mines of Katanga, Oxford: Clarendon Press.

Klasen, S. (2002), 'Low schooling for girls, slower growth for all? Cross-country evidence on the effect of gender inequality in education on economic development', The World Bank Economic Review, 16(3): 345-373.

Lindert, P.H. (2004), Growing public: Social spending and economic growth since the eighteenth century (Vol. 1), Cambridge: Cambridge University Press.

Masandi, P.K. (2004), 'L'Éducation féminine au Congo belge', Paedagogica historica, 40(4): 479-508.

Nicolaï, H. (2013), Le Congo et l'huile de palme. Un siècle. Un cycle?, Belgeo. Revue belge de géographie, $4: 1-41$.

Nunn, N. (2012), 'Gender and Missionary Influence in Colonial Africa', unpublished Working Paper.

Perrings, C. (1979), Black Mineworkers in Central Africa: Industrial Strategies and the Evolution of an African Proletariat in the Copperbelt, 1911-41, London: Heinemann Educational.

Sauerbeck, A. (1951), 'Wholesale Prices in 1950', Journal of the Statistical Society of London, 114(3): 408-422.

Titeca, K. and De Herdt, T. (2011), 'Real governance beyond the 'failed state': Negotiating education in the Democratic Republic of the Congo', African Affairs, 110(439): 213-231.

Van Reybrouck, D. (2005), Congo: the epic history of a people, New York: Harper Collins.

White, B. W. (1996), 'Talk about School: education and the colonial project in French and British Africa (1860-1960)', Comparative Education, 32(1): 9-26.

World Bank (2015), 'Public Expenditure Review of the Education Sector in the Democratic Republic of Congo An Efficiency, Effectiveness, and Equity Analysis', World Bank Working Paper. 
Appendix A: Map of the Belgian Congo showing provinces and districts, 1950s

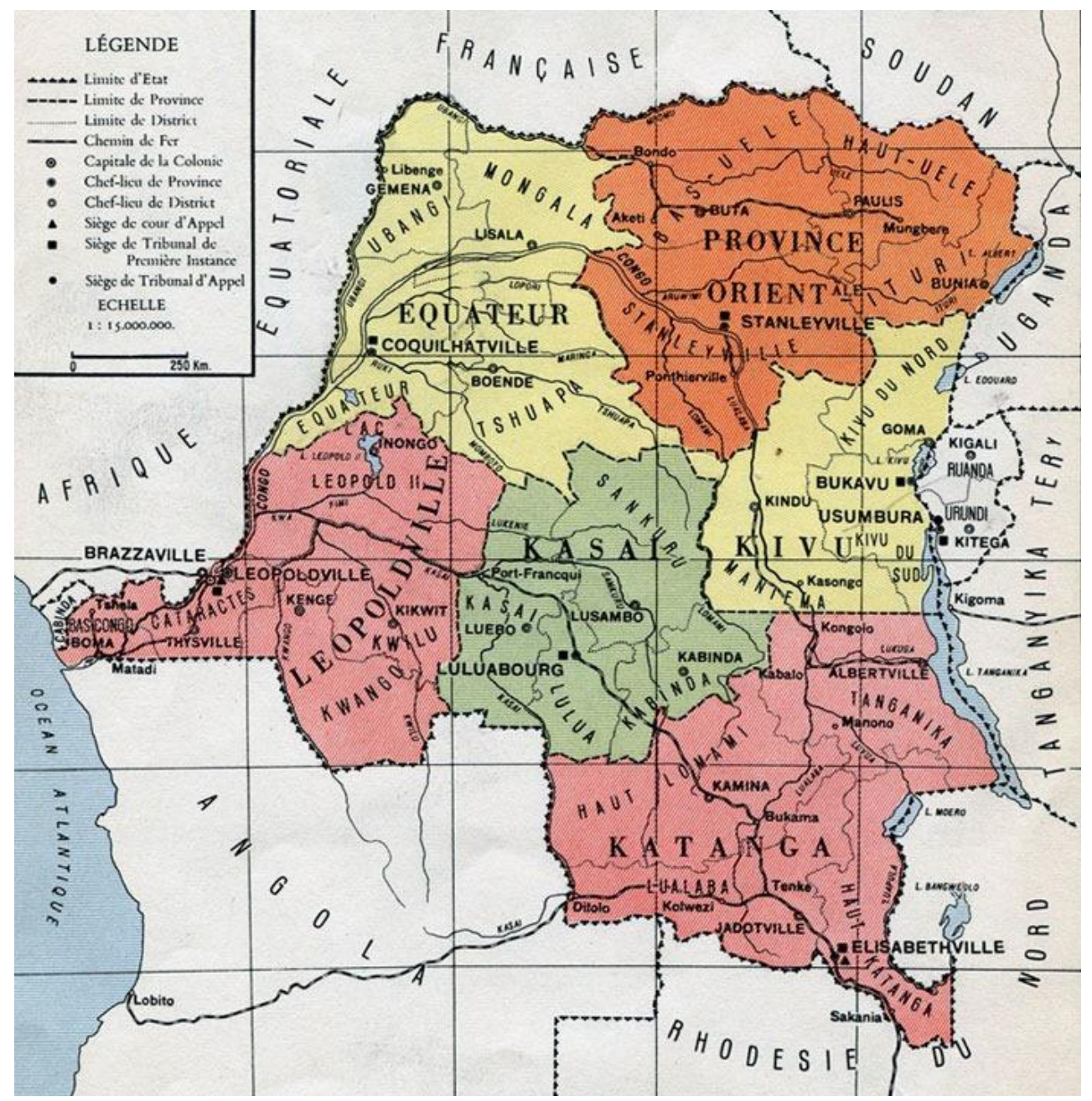

Source: Cartes géographiques du Congo Belge et du Ruanda-Urundi (1956), p. 1, accessed 18.06.2018, $<$ http://www.histoire-des-belges.be/au-fil-du-temps/epoque-contemporaine/congo-belge/les-etapes-de-la-miseen-valeur-du-congo> 
Appendix B: Overview number of schools and pupils enrolled, selected years

\begin{tabular}{|c|c|c|c|c|c|}
\hline & $1 / 1 / 1930$ & $1 / 1 / 1939$ & $1 / 1 / 1945$ & $1 / 1 / 1948$ & $1 / 1 / 1955$ \\
\hline \multicolumn{6}{|l|}{ A) Official schools } \\
\hline \multicolumn{6}{|l|}{ Number of schools: } \\
\hline Primary & 9 & 7 & 6 & 5 & \\
\hline Secondary & 4 & 4 & 3 & 4 & \\
\hline Professional (vocational) & 5 & 4 & 3 & 3 & \\
\hline Total no. of schools & 18 & 15 & 12 & 12 & \\
\hline \multicolumn{6}{|l|}{ Number of pupils: } \\
\hline Primary & 2,968 & 3,624 & 3,934 & 3,464 & $25,769 *$ \\
\hline Secondary & 72 & 282 & 257 & 313 & 1,614 \\
\hline Professional (vocational) & 576 & 282 & 278 & 355 & \\
\hline University & & & & & 42 \\
\hline Total no. of pupils & 3,616 & 4,188 & 4,159 & 4,132 & 27,425 \\
\hline Diplomas from middelschool & 143 & 102 & 96 & 89 & \\
\hline \multicolumn{6}{|l|}{ (B) Subsidized schools } \\
\hline \multicolumn{6}{|l|}{ Number of schools: } \\
\hline Primary 1 st degree & 2,532 & 4,446 & 5,020 & 6,966 & \\
\hline Primary 2nd degree & 163 & 650 & 839 & 983 & \\
\hline 6th preparatory & & & 44 & 52 & \\
\hline Normal schools & 16 & 34 & 37 & 39 & \\
\hline Secondary & 2 & 6 & 11 & 12 & \\
\hline Professional (vocational) & 5 & 3 & 8 & 8 & \\
\hline Household schools & 4 & 17 & 26 & 28 & \\
\hline Total no. of subsidized schools & 2,722 & 5,156 & 5,985 & 8,088 & \\
\hline \multicolumn{6}{|l|}{ Number of pupils: } \\
\hline Primary 1st degree & 119,563 & 195,401 & 243,918 & 320,591 & \\
\hline Primary 2nd degree & 8,162 & 47,980 & 65,840 & 84,311 & $852,701 *$ \\
\hline 6th preparatory & & & 1,630 & 1,750 & \\
\hline Normal schools & 891 & 2,038 & 2,154 & 2,471 & \\
\hline Secondary & 49 & 331 & 624 & 959 & 0003 \\
\hline Professional (vocational) & 133 & 181 & 366 & 504 & 9,903 \\
\hline Household schools & 183 & 473 & 728 & 824 & \\
\hline Religious seminar & & & & & 358 \\
\hline Total number of pupils & 128,981 & 246,404 & 315,260 & 411,410 & 862,962 \\
\hline \multicolumn{6}{|l|}{ Diplomas : } \\
\hline $\begin{array}{l}\text { from normal, secondary } \\
\text { and professional schools }\end{array}$ & 175 & 503 & 549 & 726 & \\
\hline $\begin{array}{l}\text { from secondary, official } \\
\text { and subsidized schools }\end{array}$ & 318 & 605 & 645 & 815 & \\
\hline Total diplomas & 493 & 1,108 & 1,194 & 1,541 & \\
\hline \multicolumn{6}{|l|}{ C) "Free" schools } \\
\hline \multicolumn{6}{|l|}{ Number of schools: } \\
\hline Primary & $\mathrm{n} / \mathrm{a}$ & 17,910 & 19,193 & 19,072 & \\
\hline Post-primary & $\mathrm{n} / \mathrm{a}$ & 87 & 66 & 58 & \\
\hline Total "free" schools & $\mathrm{n} / \mathrm{a}$ & 17,997 & 19,259 & 19,130 & \\
\hline
\end{tabular}


Number of pupils:

\begin{tabular}{|c|c|c|c|c|c|}
\hline $\begin{array}{c}\text { Primary } \\
\text { Post-primary } \\
\text { Total pupils "free schools" } \\
\end{array}$ & $\begin{array}{l}\mathrm{n} / \mathrm{a} \\
\mathrm{n} / \mathrm{a} \\
\mathbf{n} / \mathrm{a}\end{array}$ & $\begin{array}{c}463,950 \\
2,192 \\
\mathbf{4 6 6 , 1 4 2} \\
\end{array}$ & $\begin{array}{c}483,258 \\
1,805 \\
\mathbf{4 8 5 , 0 5 8} \\
\end{array}$ & $\begin{array}{c}513,049 \\
1,925 \\
\mathbf{5 1 4 , 9 7 4} \\
\end{array}$ & $\begin{array}{c}358,262^{*} \\
9,279 \\
\mathbf{3 6 7 , 5 4 1} \\
\end{array}$ \\
\hline \multicolumn{6}{|l|}{ Overall total } \\
\hline \multicolumn{6}{|l|}{ Number of schools: } \\
\hline Primary & & 23,013 & 25,302 & 27,078 & \\
\hline Post-primary schools & & 155 & 154 & 152 & \\
\hline Overall total schools & & 23,168 & 25,456 & 27,230 & \\
\hline \multicolumn{6}{|l|}{ Number of pupils: } \\
\hline Primary & & 710,955 & 798,265 & 923,165 & $1,236,732 *$ \\
\hline $\begin{array}{l}\text { Post-primary (secondary, } \\
\text { professional, household) }\end{array}$ & & 5,779 & 6,212 & 7,351 & 21,196 \\
\hline Overall total number of pupils & & 716,734 & $\mathbf{8 0 4 , 4 7 7}$ & $\mathbf{9 3 0 , 5 1 6}$ & $1,257,928$ \\
\hline $\begin{array}{l}\text { Share of pupils enrolled in } \\
\text { primary school }\end{array}$ & & 0.99 & 0.99 & 0.99 & 0.98 \\
\hline $\begin{array}{l}\text { Share of pupils enrolled in post- } \\
\text { primary schools }\end{array}$ & & 0.01 & 0.01 & 0.01 & 0.02 \\
\hline
\end{tabular}

Sources: Tienjarenplan voor de economische en sociale ontwikkeling van Belgisch Kongo, 1949; and Annual Report of the administration of the Colony of Belgian Congo, 1955.

*includes nursery, pre-primary and primary school. 
Appendix C : Enrolment rate (boys and girls*) per province assuming that $20 \%$ of the population are school age children

\begin{tabular}{|l|r|r|r|}
\hline \multirow{2}{*}{ Province } & \multicolumn{3}{|c|}{ Enrolment rate (\%) } \\
\cline { 2 - 4 } & $\mathbf{1 9 3 0}$ & $\mathbf{1 9 3 5}$ & $\mathbf{1 9 4 6}$ \\
\hline Katanga & 15.4 & 21.7 & 27.8 \\
\hline Kasai & 9.6 & 13.0 & 17.7 \\
\hline Leopoldville & & 8.0 & 18.2 \\
\hline Orientale & 6.7 & 11.6 & 14.4 \\
\hline Equateur & & 4.5 & 10.1 \\
\hline Kivu & & 2.7 & 7.2 \\
\hline Total Congo & 7.5 & 10.0 & 15.6 \\
\hline
\end{tabular}

Sources: Author's own calculation. Data from Annual Reports of the administration of the Colony of Belgian Congo, 1930, 1935, 1946.

* Only the total national enrolment rates include male and female pupils, because we do not know how female students are distributed between provinces. Excluding female students reduces total enrolment rates by ca. one percent.

Appendix D: Exchange rate Belgian Franc to Great British Pound

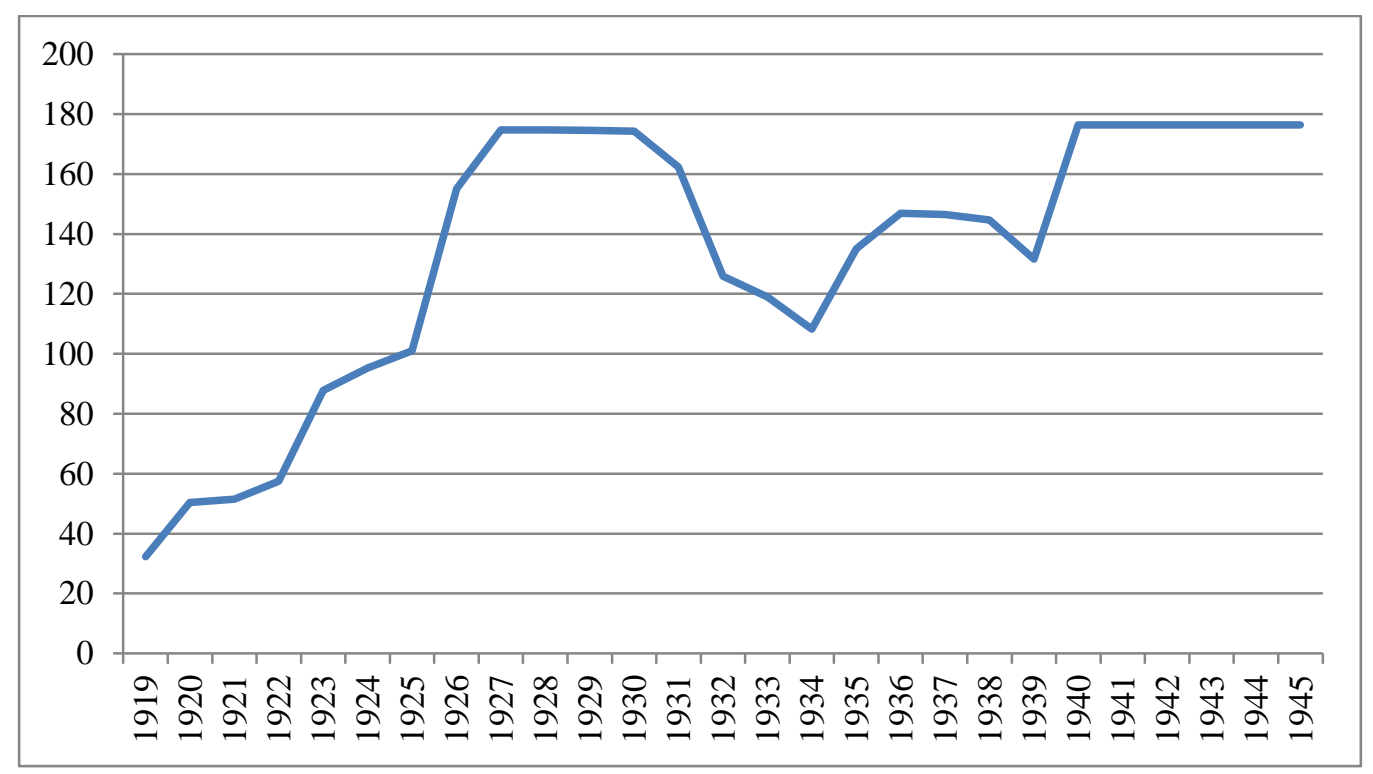

Source: Data from ClioInfra Database: https://www.clio-infra.eu/ 